\title{
Case Study of Damaged Road Surfaces as a Result of Drainage on Sabar Jaya Road Kelurahan Mariana ILIR
}

\author{
Surnata ${ }^{1}$,Bambang Setiawan ${ }^{2}$, Purboyo. ${ }^{3}$ Yuni Karlina ${ }^{4}$ \\ Inland Water and Ferries Transport Polytechnic of Palembang, Palembang City, Indonesia
}

\begin{abstract}
Banyuasin Regency in addition to having a strategic geographical location that is located in the inter-provincial route also has abundant natural resources. Geographical Location Banyuasin Regency is located in a position between $1.30 \circ-4.0{ }^{\circ}$ South Latitude and $104^{\circ} 00$ '- $105{ }^{\circ} 35^{\prime}$ East Longitude that starts from the central part of the Province of South Sumatra to the East. Banyuasin Regency has an area of $12,431 \mathrm{~km}^{2}$ and is divided into 19 districts, one of which is Banyuasin I. The Jalan Pati jaya is Jalan Kecamatan, which is located in the Sub-district of Mariana ilir, Subdistrict of Banyuasin I. This road only connects the Mariana sub-district to the village of Prajin. the current condition of the road has been intersected with the proboscis river where the condition of the road has been damaged due to inundation of rain water, in addition to the inundation of the soil the quality is still unstable and the road surface is also thin. And dranase channels are currently in a mapet state. On the subject matter above the author only examines and analyzes three elements, among others.
\end{abstract}

The aspect of Hydrology is the science relating to water on earth, both regarding its occurrence, circulation and distribution, its properties and its relationship with the environment, especially with living things. The large number of parameters makes hydrological analysis difficult to solve analytically. Besides that hydrological conditions depend on changes / activities carried out by humans such as changes in land use. (Triatmodjo, 2008 h 1)

Keywords:- Road Surface; Hydrological Analysis.

\section{INTRODUCTION}

Banyuasin Regency in addition to having a strategic geographical location that is located in the inter-provincial route also has abundant natural resources. Geographical Location Banyuasin Regency is located in a position between $1.30^{\circ}-4.0^{\circ}$ South Latitude and $104^{\circ} 00^{\prime}-105^{\circ}$ $35^{\prime}$ East Longitude that starts from the central part of the Province of South Sumatra to the East.

Banyuasin Regency has an area of $12,431 \mathrm{~km}^{2}$ and is divided into 19 districts, one of which is Banyuasin I District.
The Jalan Pati jaya is Jalan Kecamatan, which is located in the sub-district of Mariana ilir, sub-district of Banyuasin I. This road is the only one connecting the subdistrict of Mariana ilir with the village of Prajin. the current condition of the road has been intersected with the proboscis river where the condition of the road has been damaged due to inundation of rain water, in addition to being flooded. With the destruction of road traffic in the form of truck vehicles, public transportation vehicles and motorcycle vehicles become disrupted and worrying about the safety of road users to be disrupted in traffic safety.

What's more when the water is stagnant on the road surface, many road users are trapped by small deep holes and flooded by water, especially many motorcycle users who fall and roll on the damaged road surface. In addition to roads with potholes the quality of the basic soil is also a subgrade so that the soil movement becomes unstable.

The role of the road strongly supports all community activities that need to be maintained in a sustainable manner so that it functions optimally according to its standards. Road standards are a reference for the physical embodiment of transportation infrastructure that uses land, established with minimum criteria in accordance with the facilities that must be served according to travel that has been carried out safely, quickly, cheaply and comfortably.

The road is determined by its existence in a space called the road benefit space, the space owned by the road, the road supervision room. This is prepared to ensure the smoothness and safety of road users, besides that good construction is also needed to ensure the safety of road users.

The aspect of hydrology is the science relating to water on earth, both regarding its occurrence, distribution and distribution, its properties and its relationship with the environment, especially with living things. The large number of parameters makes hydrological analysis difficult to solve analytically. Besides that hydrological conditions depend on changes / activities carried out by humans such as changes in land use. (Triatmodjo, $2008 \mathrm{~h} \mathrm{1)}$

Measurement of Rain Rain is a very important component in the hirological analysis of discharge planning to determine the dimensions of drainage channels. Measuring rain carried out for 24 hours in this way means the known rain is the total rain that occurred during 1 day. For various purposes of drainage planning. 
Rainfall data needed is not only daily rain data but also hour-or-minute distribution. This will have consequences in the selection of data and it is recommended to use rain data measurement results with automatic measuring devices.

Drainage In general, drainage systems can be defined as a series of water structures that function to reduce or remove excess water from an area / land, so that the land can be used optimally. The drainage system building sequentially starting from the upstream consists of a receiving channel (interceptor drain), a collector drain, a conveyor drain, a main drain, and receiving water bodies (receiving waters). Throughout the system, other buildings are often found, such as culverts, bridges, gutters and sloped canals (Suripin, 2004).

\section{RESEARCH METHODOLOGY}

This data collection research methodology uses several methods of approach in getting data as a reference and comparison. This approach is adapted to the conditions and location of the place where the object is located. The data obtained in this study are as follows:

\section{Primary data}

Is data obtained directly from the source, observed and recorded from what happened in the field. In obtaining primary data the author uses observation is to make direct observations about the actual conditions in the field, namely observation:

- Soil excavation with the function of checking the consolidation of subgrade on a damaged road surface, in order to determine the soil layer. Data measurement of damaged road dimensions through direct measurement in the field, and daily data collection of average passing vehicles;

- Rainfall measurement data with the function of knowing, the amount of average rainfall in the location of the damaged road; Polygon Thiessen method, and Isohiet method (Suripin, 2004).

The usual method used in calculating rainfall intensity is as follows:

t:

* Metode Mononobe

$$
I=\frac{R_{24}}{24}\left(\frac{24}{t}\right)^{\frac{2}{3}}
$$

\section{Dimana :}

I : Intesitas Curah Hujan (mm/jam)

$t$ : Lamanya Curah Hujan / Durasi Curah Hujan

(jam)

$R_{24} \quad$ : Curah Hujan Rencana Dalan suatu priode yang nilainya

di dapat daritahan sebelumnya $R_{24}$ dapat diartika sebagai curah hujan dalam 24 jam $(\mathrm{mm} / \mathrm{hari})$

\section{* Metode Van Breen}

Based on research by Ir. Van Breen in Indonesia, especially in Java, rainfall is concentrated for 4 hours with a total rainfall of $90 \%$ of the total rainfall for 24 hours. The rainfall intensity formulation using the Van Breen Method is as follows:

$$
I_{T}=\frac{54 R_{T}+0,07 R_{T}^{2}}{t_{c}+0,3 R_{T}}
$$

dimana :

$I_{T} \quad:$ Intensitas curah hujan pada suatu periode ulang ( $\mathrm{T}$ tahun)

$R_{T} \quad$ : Tinggi curah hujan pada periode ulang $\mathrm{T}$ tahun (mm/hari)

\section{* Metode Haspers dan Der Weduwen}

This method is derived from the tendency of daily rainfall which is grouped on the basis of the assumption that rainfall has a symmetrical distribution with a duration of rainfall less than 1 hour and a duration of rainfall less than 1 to 24 hours Formulation of rainfall intensity using the Haspers \& der Method Weduwen is as follows:

$$
R_{i}=X_{t}\left(\frac{1218 t+54}{X_{t}(1-t)+1272 t}\right)
$$

Where:

$t \quad$ : Rain duration is 1 hour

$X_{r} \quad$ : Selected maximum rainfall

$$
\begin{aligned}
& I=\frac{R}{t} \\
& \text { Untuk } 1 \leq t<24 \text { jam : } \\
& R=\sqrt{\frac{11300 t}{t+3,12}}\left[\frac{X_{i}}{100}\right]
\end{aligned}
$$

Dimana :

$$
\begin{array}{ll}
I & \text { : Intensitas curah hujan }(\mathrm{mm} / \mathrm{jam}) \\
R, R t & \text { : Curah hujan menurut Haspers dan Der Weduwen } \\
t & : \text { Durasi curah hujan (jam) } \\
X t & : \text { Curah hujan harian maksimum yang terpilih } \\
(\mathrm{mm} / \mathrm{hari}) &
\end{array}
$$

By using a rainfall gauge

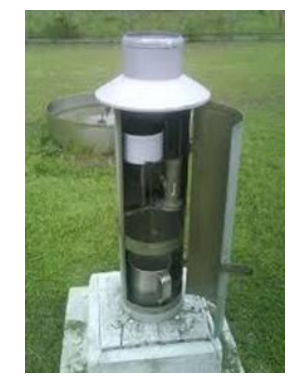

Fig 1:- Rainfall Gauge 
Retrieval of rainwater drainage velocity with functions for drainage planning. Use the Chezy Manning formula

\section{* Rumus Chezy Manning}

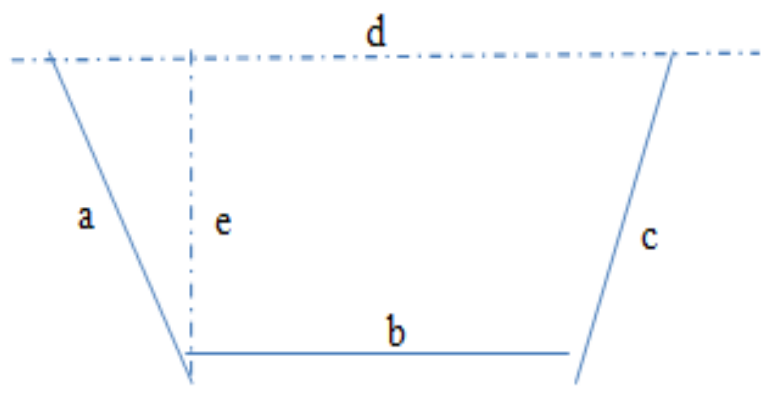

Fig 2

Hidrolic Radius = ----

$$
\mathrm{P}=\text { Penampang Basah }
$$

$$
\mathrm{b}+\mathrm{d}
$$

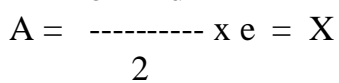

$\mathrm{P}=\mathrm{a}+\mathrm{b}+\mathrm{c} \quad=\mathrm{Y}$

$$
\mathrm{X}
$$

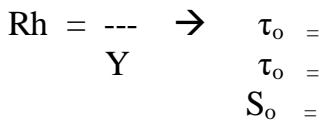

$\gamma \mathrm{Rh} \mathrm{S}_{\mathrm{o}}$

$\tau_{\mathrm{o}}=$ Gaya Gesek Rata-rata

saluran)

Chanel Slop (kemiringan dasar

\section{Secondary Data}

Data obtained indirectly, obtained from relevant agencies. Literature data and related regulatory regulations concerning road standard rules.

\section{DISCUSSION AND DISCUSSION RESULTS}

\section{A. Discussion \\ $>$ Land Condition Check}

The author has conducted basic soil research. By means of soil excavation, if it is seen from the results of excavation that the soil is a dense pile in the landfill area, and above the landfill is in the type of clay so that the dense pile presses the clay into soil until there is land subsidence. With the automatic land subsidence that has been planned in accordance with the height of the road will gradually go down, with the decrease in the road to cause the land to become sloping due to the heavy burden he bears.

\section{Measurement of Damaged Road Areas}

Location measurement data, this is done how much impact the location of the damaged area. From observations in the field, measurements of the road that was damaged due to waterlogging and the burden of vehicles traveling through the road have been carried out:
Length
: 15 Meters
Width
: 5 Meters
area of : 75 meters

\section{Vehicle Data}

From the observations in the field, the author has taken a number of samples of vehicles passing the road per day :

\begin{tabular}{|c|c|c|c|c|}
\hline No & Date & Truk & Angkot & Motor \\
\hline 1 & $03-4-2020$ & 130 & 8 & 256 \\
\hline 2 & $05-5-2020$ & 168 & 12 & 205 \\
\hline 3 & $25-5-2020$ & 125 & 10 & 182 \\
\hline 4 & $12-6-2020$ & 136 & 11 & 267 \\
\hline 5 & $10-7-2020$ & 198 & 12 & 261 \\
\hline \multicolumn{2}{|c|}{ Rata-rata } & $\mathbf{1 5 2}$ & $\mathbf{1 1}$ & $\mathbf{2 3 4}$ \\
\hline
\end{tabular}

Table 1:- Vehicle Data that Passes on Jalan Sabar Jaya Data from the 2020 survey

\section{Rainfall data}

Rainfall intensity is the amount of rainfall expressed in terms of the height of the rainfall or the volume of rain per unit time, which occurs in a period of time concentrated rainwater (Wesli, 2008).

The amount of rainfall intensity varies depending on the length of rainfall and the frequency of occurrence. High rainfall intensity generally takes place with a short duration and covers areas that are not extensive. Rain that covers large areas, rarely with high intensity, but can take place with a fairly long duration. The combination of high rainfall intensity with long duration is rare, but if it happens it means that a large amount of volume of water is like being poured out of the sky. (Suroso, 2006). its function is to find out how much the volume of standing water at the location of the damaged road. And how big is the speed of rainwater in its drainage. This has been carried out checking rain every time the rain falls. And what is the amount of rainwater that enters the surface area.

From measurements using mathematical authors choose the measurement of rainfall using practical tools. From the results that have been taken from the following practical tools, among others: 
ISSN No:-2456-2165

\begin{tabular}{|c|c|c|c|c|}
\hline Tanggal & Durasi Waktu & $\begin{array}{c}\text { Intensisas Curah Hujan } \\
(\mathrm{mm} / \mathrm{jam})\end{array}$ & $\begin{array}{c}\text { Area Lokasi Permukaan } \\
\text { Jalan Yang Rusak }\left(\mathrm{m}^{2}\right)\end{array}$ & $\begin{array}{c}\text { Intensitas Curah Hujan } \\
\left(\mathrm{m}^{3} / \mathrm{jam}\right) \\
\text { Dilapangan }\end{array}$ \\
\hline $04 / 03 / 2020$ & 5 Menit & 394.46 & 75 & 29.584 \\
\hline $08 / 03 / 2020$ & 110 Menit & 788.92 & 75 & 59.169 \\
\hline $10 / 04 / 2020$ & 15 Menit & 439.46 & 75 & 32.959 \\
\hline $25 / 05 / 2020$ & 60 Menit & 521.21 & 75 & 39.090 \\
\hline $12 / 06 / 2020$ & 130 Menit & 888.92 & 75 & 66.669 \\
\hline \multicolumn{2}{|c|}{ Jumlah Rata rata } & 49.494 \\
\hline
\end{tabular}

Table 2:- Rainfall Intensity

By Using Rainfall Measuring Devices

Source of Survey Results Data 2020

\section{$>$ Analysis of Drainage Plans}

In general drainage is defined as the science that studies efforts to drain excess water in a particular user context. Drainage System In general, drainage systems can be defined as a series of water structures that function to reduce or remove excess water from an area / land, so that the land can be used optimally.

From the observation of rainfall, to determine in advance how much drainage the rain water flow and the average flow rate of the water that flows to the location. After obtaining it, then design the drainage dimensions using the hydraulic analysis formula.

Theory states "The hydraulic aspect of liquid substances can be transported from one place to another through natural or man-made buildings. This carrier building can be open or closed at the top. Channels that are closed at the top are called closed channels, while those that are open at the top are called open channels. Rivers, irrigation channels, gutters are open channels, while pipes, culverts are closed channels"(Suripin, 2004 p119).

From what has been described above, the writer has checked the flow of water using a simple measuring instrument, obtaining an average yield $=0.0699 \mathrm{~m} / \mathrm{d}$. The author formulates the chezy manning formula as follows:

\section{B. Discussion Result}

In this discussion is a continuation of Chapter I, Chapter II and Chapter III. Which answers from the formulation of the problem that has been stated and explained above.

Is the existing road on the patient road glorious precisely bridged river proboscis already standard?

From the above questions, clearly it is still not perfect and far from standard quality infrastructure. the results of the discussion above about checking the soil that begins with clay soils after that there is hard pile, which results in land subsidence, and what if there is land subsidence if there is rain water inundation due to dense flooding.

With the land subsidence, it is better if there is an addition of landfill so that there is no more slope of the tersut land. and according to the standardization of the road. In accordance with government policy Several statutory products that regulate the integration of safe transportation are as follows. Law 38/2004 along with PP.no.34 / 2006 concerning roads and Law.14 / 1993 concerning road traffic and transportation along with PP 43/1993 concerning transportation infrastructure, regulates the classification of roads in accordance with the character of travel and the characteristics of road users' vehicles presented through the speed and weight of the vehicle.

Basically, it becomes the minimum standard size to realize the safety of land transportation using roads, as well as for the realization of transportation infrastructure, which refers to this Law standardizing the use of roads regulated in accordance with applicable laws and regulations. And in the Bibliography it has also been told that road infrastructure must comply with standards. with functions for the safety of road users.

\section{Does rainwater discharge affect the making of Drainage?}

From the above questions, the linkage of the results of the discussion on determining the rainfall that has been taken in a sample and answering the question in the problem formulation is the process of decreasing the surface of the road so that when the rainwater drains the drainage other than clogged. The rainwater flows to the road surface with an average number of 49,494 M3, resulting in a pool of rain water. Taking this sample is not only to find out the amount of water that has stagnated on the damaged surface. This measurement of rainfall is continuous to determine the velocity of rainwater flow. The author has measured the average velocity of rainwater drainage $=0.0699 \mathrm{~m} / \mathrm{d}$, so it is clear with the speed of rainwater drainage as material for Drainage planning.

\section{> How to determine drainage planning. ?}

From the above questions, the interrelation of the results of the discussion in chapter III that from the calculation results to determine drainage planning results include the following:

$$
\begin{aligned}
& \text { lebar atas } \\
& \text { lebar bawah } \\
& =0.75 \mathrm{~m} \\
& \text { kedalaman aliran } \\
& =0.50 \mathrm{~m} \\
& \text { kemiringan dasar } \\
& \text { koefisien Chezy adalah }=40 \text {. } \\
& \text { Luas tampang aliran } \quad: A \quad=1 / 2(B 1+B 2) \cdot h \\
& 1 / 2(0.70+0.40) \cdot 0.50=2.75 \mathrm{~m} 2
\end{aligned}
$$


$\begin{array}{ll}\text { Keliling basah } \quad: P \quad= & B+2 h \\ & 2.75+2 \times 0.40=3.55 \mathrm{~m}\end{array}$

Jari-jari hidraulis $: R=A / P$ $=2.75 / 3.55$

$=2.7746 \mathrm{~m}$

Kecepatan aliran $: V=\mathrm{C} \sqrt{\mathrm{R}} \mathrm{I}$

$=40 \sqrt{ } 0.75 \times 0,0005$

$$
=0.0699 \mathrm{~m} / \mathrm{d}
$$

$\mathrm{Q} \quad=\mathrm{V} \cdot \mathrm{A}$

$=0.0699 \mathrm{~m} / \mathrm{d} \times 2.75$

$=0.1922 \mathrm{~m}^{3} / \mathrm{d}$

Information with average water velocity $=0.0699 \mathrm{~m} /$ $\mathrm{d}$, with the planned dimensions we get a water discharge $\mathrm{Q}$ $=0.1922 \mathrm{~m} 3 / \mathrm{sec}$

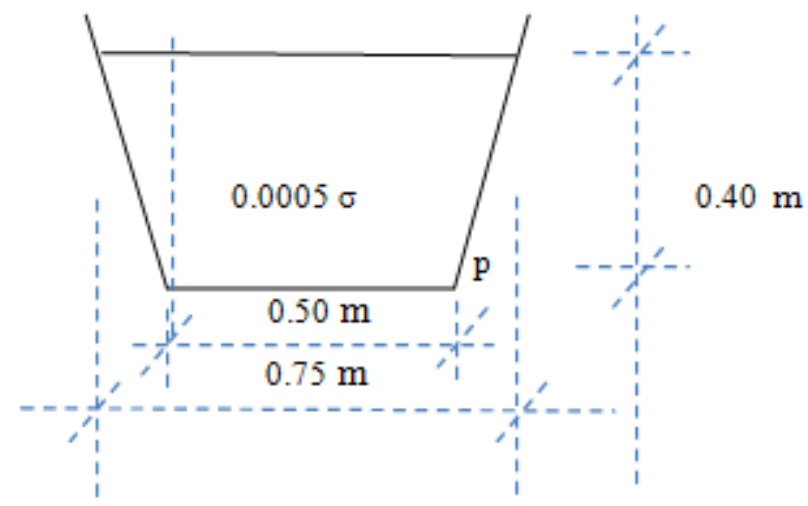

Fig 3:- Image of Drainage Plan

\section{CONCLUSIONS AND RECOMMENDATIONS}

\section{A. Conclusion}

Checking the condition of the location, road, If seen from the results of excavation that the land is a dense pile in the landfill area, and the pile is in clay so that the dense pile presses the clay into clay until there is land subsidence. measurement of roads damaged by stagnant water and vehicle loads that pass through the road by:

Length: 15 Meters1 Width: 5 Meters1 Width: 75 Meters 2

For conducting surveys. The author only does a sample of daily vehicle data: Survey 1. Conducted on 4/4/2020, Survey 2. Conducted on 5/5/2020, Survey 3. Conducted on 5/25/2020 Survey 4. Conducted on $12 /$ $6 / 2020$ and Survey 5 was conducted on 10/7/2020. Types of truck vehicles with an average number of 152 truck vehicles. The average number of angkot vehicles is 11 angkot vehicles and the average number of motorbike vehicles is 234 motorbikes.

The amount of rainfall intensity varies depending on the length of rainfall and the frequency of occurrence. High rainfall intensity generally takes place with a short duration and covers areas that are not extensive. Rain that covers large areas, rarely with high intensity, but can take place with a fairly long duration. The combination of high rainfall intensity with long duration is rare, but if it happens it means that a large amount of volume of water is like being poured out of the sky. (Suroso, 2006).

Its function is to find out how much the volume of standing water at the location of the damaged road. And how big is the speed of rainwater in its drainage. This has been carried out checking rain every time the rain falls. And the speed of rainwater drainage which serves to plan drainage. In general drainage is defined as the science that studies efforts to drain excess water in a particular user context. Drainage System In general, drainage systems can be defined as a series of water structures that function to reduce or remove excess water from an area / land, so that the land can be used optimally.

From the observation of rainfall, in order to determine the drainage in advance how much the rain water debit and the average flow rate of the water flowing to the location. After obtaining it, then design the drainage dimension by using the hydraulic analysis formula. From what has been described above, the writer has checked the flow of water using a simple measuring instrument, obtaining an average yield $=0.0699 \mathrm{~m} / \mathrm{d}$. with the planned dimensions we get a water discharge $\mathrm{Q}=0.1922 \mathrm{~m} 3 / \mathrm{sec}$

\section{B. Suggestions}

$>$ Road Construction

With this land subsidence, it is better to add more landfill and build roads according to the type of vehicles passing and according to the classification of vehicles that will pass through and in accordance with the standardization of the road. from government policy Several statutory products regulating the integration of safe transportation are as follows. Law 38/2004 along with PP.no.34 / 2006 concerning roads and Law.14 / 1993 concerning road traffic and transportation along with PP 43/1993 concerning transportation infrastructure, regulates the classification of roads in accordance with the character of travel and the characteristics of road users' vehicles presented through the speed and weight of the vehicle, Basically it becomes the minimum standard size to realize road transportation safety using road, as well as for the realization of transportation infrastructure, which refers to this Act standardizing the use of the road regulated in accordance with applicable laws and regulations. In connection with what has been mentioned above, the writer suggests, the government should implement supervision in the field of road infrastructure so that the road is well maintained in accordance with what is stated in the road safety standards.

\section{Rainfall}

The amount of rainfall intensity varies depending on the length of rainfall and the frequency of occurrence. High rainfall intensity generally takes place with a short duration. Checking rainfall, its function is to find out how much the volume of standing water at the location of the damaged road and measure the speed of rainwater flow. 
Researchers have conducted a survey, by recording the rainwater flowing to the surface of damaged roads with an average amount of $59.16 \mathrm{~m} 3$ and measuring the average velocity of rainwater drainage $=0.0699 \mathrm{~m} / \mathrm{sec}$. From the data recording above the authors suggest:

- By recording the volume of water, so that the government authorities immediately renovate the road so that there will be no more water puddles by carrying out road repairs;

- By recording the speed of the rainwater, the data is used as a basis for drainage planning. After obtaining average results $=0.0699 \mathrm{~m} / \mathrm{sec}$, then plan dimensions according to standard

\section{Drainage}

From the observation of rainfall, in order to determine the drainage in advance how much the rain water discharge and the average speed of the water flowing to the location. After obtaining it, then design the drainage dimension using the Chezy Manning formula.

The author suggests:

- The dranase is made to comply with the standards required in the design of the road geometry, every road must have drainage. So that water does not flow again to the road surface;

- Giving input to the Road Guidance, so that the road needs to be noticed, and pay attention to the safety of road users.

\section{REFERENCES}

[1]. Culverts, bridges, gutters and slanted drains (Suripin, 2004).

[2]. American Association Of State Highway \& transportation Officials (AASHTO), 200, A policy on geometric design of highways and states, publisher by AASHTO, Washington DC.

[3]. Law.14 / 1993 concerning road traffic and transportation

[4]. PP 43/1993 concerning transportation infrastructure, regulates the classification of roads in accordance with the character of the trip and the character of the road user vehicle that is presented through the speed and weight of the vehicle. 